\title{
PERUBAHAN KONDISI SOSIAL EKONOMI MASYARAKAT PULAU GILI KETAPANG KECAMATAN SUMBERASIH KABUPATEN PROBOLINGGO SEBAGAI DAMPAK ADANYA OBYEK WISATA SNORKELING
}

\author{
Dimas Angga Afrianto ${ }^{1}$, Sukidin ${ }^{1}$, Pudjo Suharso ${ }^{1}$ \\ ${ }^{1}$ Program Studi Pendidikan Ekonomi, Fakultas Keguruan dan Ilmu Pendidikan, Universitas Jember \\ e-mail: 140210301057@students.unej.ac.id
}

\begin{abstract}
Abstrak
Kondisi lingkungan Pulau Gili Ketapang dapat dikatakan buruk dikarenakan kurangnya kesadaran masyarakat yang banyak melakukan penambangan pasir di sekitar pantai untuk dijadikan sebagai bahan bangunan yang pada akhirnya juga mengakibatkan kerusakan di daratan maupun ekosistem laut. Keberadaan obyek wisata snorkeling dapat memperbaiki kondisi lingkungan di Pulau Gili Ketapang serta meningkatkan kesejahteraan masyarakat lokal Pulau Gili Ketapang. Penelitian ini menggunakan jenis penelitian deskriptif dengan pendekatan kualitatif yang bertujuan untuk mendeskripsikan secara jelas mengenai fakta-fakta yang terjadi di lapangan terkait dengan perubahan kondisi sosial ekonomi masyarakat Pulau Gili Ketapang sebagai dampak adanya obyek wisata snorkeling. Hasil penelitian menunjukkan bahwa dari segi sosial, masyarakat Pulau Gili Ketapang telah mengalami kemajuan pola pikir, terbuka, dan inovatif terkait dengan pekerjaan dengan cara memanfaatkan segala potensi yang dimiliki Pulau Gili Ketapang untuk kesejahteraaan masyarakat. Interaksi sosial yang terjadi antara masyarakat dengan para wisatawan menjadikan masyarakat melek akan kemajuan teknologi, ilmu pengetahuan dan pengalaman yang semakin meningkat. Dari segi ekonomi, keberadaan obyek wisata snorkeling memunculkan jenis lapangan pekerjaan baru yang mampu menyerap tenaga kerja dari usahausaha yang didirikan oleh masyarakat lokal diantaranya yaitu jasa transportasi perahu, jasa snorkeling, kuliner, dan penjualan souvenir. Hal tersebut membuat pengangguran khususnya para generasi muda Pulau Gili Ketapang dapat berkurang dan pendapatan masyarakat mengalami peningkatan yang signifikan.
\end{abstract}

Kata kunci: Pariwisata, Perubahan Sosial Ekonomi, Snorkeling.

\section{PENDAHULUAN}

Pariwisata dapat dijadikan sebagai prioritas pembangunan karena dianggap mampu meningkatkan kondisi keuangan daerah dan negara dengan jangka waktu yang lebih cepat daripada sektor komoditas lainnya. Setiap daerah memiliki beragam potensi-potensi unggulan yang dapat dieksplorasi keindahan maupun keunikannya dan mengemasnya menjadi sebuah destinasi pariwisata, tak terkecuali dengan Kabupaten Probolinggo yang juga memanfaatkan sektor pariwisata karena berpotensi untuk meningkatkan kesejahteraan masyarakat. Pariwisata menurut Undang-undang Nomor 10 Tahun 2009 tentang Kepariwisataan adalah berbagai macam kegiatan wisata dan didukung berbagai fasilitas serta layanan yang disediakan oleh masyarakat, pengusaha, dan pemerintah.

Kabupaten Probolinggo menyimpan satu lokasi yang memiliki keindahan alam yang luar biasa namun baru tersentuh oleh pengembangan pariwisata berupa sebuah pulau bernama Gili Ketapang yang terletak di tengah laut sebelah utara diantara selat madura. Mayoritas penduduk di Pulau Gili Ketapang adalah orang keturunan Madura dan sebagian besar mata pencahariannya adalah berprofesi sebagai nelayan pencari ikan dan sebagian berprofesi sebagai tukang ojek kapal. Menurut data yang diperoleh dari BPS katalog Kecamatan Sumberasih dalam Angka Tahun 2017, jumlah penduduk Pulau Gili Ketapang saat ini adalah sebanyak 8.680 jiwa dengan luas wilayah sebesar 61 hektar. Jumlah tersebut sebenarnya telah jauh berkurang. Wawancara dengan Enji Syairosi, pemuda asli Pulau Gili Ketapang, tanggal 9 Desember 2017 di rest area obyek wisata snorkeling, mengatakan bahwa dahulu sebenarnya Pulau Gili Ketapang memiliki luas wilayah kurang lebih sekitar 68 hektar, namun setiap tahunnya luas wilayah tersebut semakin berkurang dikarenakan kekayaan alam Pulau Gili Ketapang seperti pasir pantai yang putih banyak diambil dan digunakan untuk bahan bangunan sehingga menimbulkan kerusakan lingkungan.

Seseorang bernama Lailul Marom adalah salah satu pemuda yang merintis berdirinya obyek wisata snorkeling di Pulau Gili Ketapang sejak tahun 2015. Snorkeling merupakan salah satu pilihan yang dapat dimanfaatkan untuk dapat melestarikan, mengeksplor keindahan dan kekayaan bawah laut yang dimiliki Pulau Gili Ketapang dengan cara menyelam diatas permukaan air menggunakan peralatan selam dasar yang terdiri dari mask sebagai pelindung wajah dan hidung, snorkel yang berbentuk J sebagai alat bantu pernafasan, dan fins atau kaki katak yang berfungsi sebagai penggerak atau pendorong ketika di dalam air. Pengelolaan dan pengembangan obyek wisata snorkeling di Pulau Gili Ketapang tentunya membawa dampak pengiring yang luas 
dan signifikan bagi masyarakat. (Gunn and Var dalam Maruwu, 2017) mengemukakan bahwa suatu kawasan wisata yang baik dan berhasil secara optimal didasarkan pada beberapa aspek, yaitu mempertahankan kelestarian lingkungannya, meningkatkan kesejahteraan masyarakat di kawasan tersebut, menjamin kepuasaan pengunjung, meningkatkan keterpaduan dan kesatuan pembangunan masyarakat disekitar kawasan dan zona pengembangan.

Keberadaan obyek wisata snorkeling ini menimbulkan pergeseran pada mata pencaharian masyarakat lokal Pulau Gili Ketapang. Sebagian masyarakat lokal Pulau Gili Ketapang sudah tidak lagi bergantung pada hasil laut dan mulai bergeser pada sektor pariwisata. Pada aspek ekonomi diharapkan dapat meningkatkan pendapatan masyarakat melalui potensi usaha dan jenis lapangan pekerjaan baru selain nelayan yang merupakan pekerjaan mayoritas. (Stynes dalam Disbudpar Banten, 2013:20) mengelompokkan dampak ekonomi menjadi 3 bagian sebagai berikut:

a) Direct effect meliputi penjualan, kesempatan kerja, pendapatan pajak, dan tingkat pendapatan

b) Indirect effect, meliputi perubahan tingkat harga, perubahan mutu dan jumlah barang dan jasa, perubahan dalam penyediaan properti dan variasi pajak, serta perubahan sosial dan lingkungan

c) Induced effects, yaitu pengeluaran rumah tangga dan peningkatan pendapatan.

Disamping itu, adanya obyek wisata snorkeling juga akan berdampak langsung pada kehidupan sosial masyarakat. Menurut (Ogburn dalam Djazifah, 2012:5) yang menjelaskan bahwa perubahan sosial menekankan kepada kondisi teknologis yang menyebabkan terjadinya perubahan pada aspek-aspek kehidupan sosial, seperti kemajuan ilmu pengetahuan dan teknologi yang sangat berpengaruh terhadap pola pikir masyarakat. Jumlah kunjungan wisatawan rata-rata mampu mencapai kurang lebih sekitar 1000 orang pada hari libur, kurang lebih 300 orang pada hari biasa, dan pada kondisi paling sepi masih mampu mencapai 100 orang wisatawan (Buku Manual Kunjungan Wisatawan Tahun 2017). Masyarakat lokal akan lebih banyak berinteraksi dengan wisatawan yang berasal dari luar daerah atau bahkan dari luar negeri. Interaksi sosial tersebut diharapkan dapat mendorong dan merubah pola pikir masyarakat menjadi lebih inovatif dalam melihat segala potensi yang ada di Pulau Gili Ketapang untuk dapat dimanfaatkan dalam meningkatkan pendapatan. Berdasarkan hal tersebut, maka menarik untuk diteliti mengenai Perubahan Kondisi Sosial Ekonomi Masyarakat Pulau Gili Ketapang Kecamatan Sumberasih Kabupaten Probolinggo Sebagai Dampak Adanya Obyek Wisata Snorkeling.

\section{METODE PENELITIAN}

Penelitian ini menggunakan jenis penelitian deskriptif dengan pendekatan kualitatif yang bertujuan untuk mendeskripsikan secara jelas mengenai fakta-fakta yang terjadi di lapangan terkait dengan perubahan kondisi sosial ekonomi masyarakat Pulau Gili Ketapang sebagai dampak adanya obyek wisata snorkeling. Penentuan lokasi penelitian menggunakan metode purposive area dengan pertimbangan bahwa telah terjadi pergeseran mata pencaharian masyarakat dari masyarakat nelayan menuju masyarakat yang bergerak di sektor pariwisata dan banyak melibatkan masyarakat Pulau Gili Ketapang. Pengumpulan data menggunakan metode observasi, wawancara, dan dokumen. Analisis data terbagi menjadi tiga tahapan yaitu reduksi data, penyajian data, dan penarikan kesimpulan/verifikasi. Uji keabsahan data menggunakan teknik triangulasi pengumpulan data.

\section{HASIL DAN PEMBAHASAN}

\section{Hasil Penelitian}

\section{Aktivitas Ekonomi Pada Obyek Wisata Snorkeling Pulau Gili Ketapang}

Diketahui bahwa sebelumnya kondisi lingkungan Pulau Gili Ketapang dapat dikatakan buruk dikarenakan kurangnya kesadaran masyarakat yang banyak melakukan penambangan pasir di sekitar pantai untuk dijadikan sebagai bahan bangunan yang pada akhirnya juga mengakibatkan kerusakan di daratan berupa berkurangnya luas wilayah Pulau Gili Ketapang yang awalnya memiliki luas wilayah kurang lebih sekitar 68 hektar namun saat ini menjadi 61 hektar. Selain di daratan, kerusakan juga terjadi pada ekosistem laut yaitu berupa banyaknya terumbu karang yang rusak dan membuat ikan-ikan di sekitar Pulau Gili Ketapang jumlahnya menjadi berkurang. Untuk mengatasi hal tersebut, salah satu cara yang dipilih yaitu dengan menjadikan Pulau Gili Ketapang sebagai obyek wisata snorkeling. Keberadaan obyek wisata snorkeling tersebut selain dapat memperbaiki kondisi lingkungan di Pulau Gili Ketapang, ternyata juga dapat memperbaiki kondisi perekonomian dan meningkatkan kesejahteraan masyarakat lokal Pulau Gili Ketapang dengan munculnya peluang usaha yang dapat dimanfaatkan masyarakat Pulau Gili Ketapang.

Pulau Gili Ketapang yang saat ini mengalami perkembangan menjadi suatu daerah wisata bahari telah membawa dampak positif bagi masyarakat lokal. Perkembangan wisata tersebut memberikan banyak peluang usaha yang telah dimanfaatkan oleh masyarakat lokal Pulau Gili Ketapang dengan cara menyediakan saranasarana terkait dengan pariwisata demi memudahkan dan memenuhi kebutuhan barang dan jasa para wisatawan. 
Dari hasil penelitian, Pulau Gili Ketapang memiliki empat komponen utama dalam mendukung kepariwisataannya diantaranya yaitu transportasi perahu, jasa snorkeling, kuliner, dan souvenir. Tanpa adanya keempat komponen utama tersebut maka kepariwisataan di Pulau Gili Ketapang tidak akan terjadi yang pada akhirnya juga tidak akan merubah sosial ekonomi masyarakat Pulau Gili Ketapang menjadi lebih baik lagi.

\section{Perubahan Kondisi Sosial Ekonomi Masyarakat Pulau Gili Ketapang}

Munculnya berbagai jenis usaha baru yang dijalankan oleh masyarakat lokal Pulau Gili Ketapang di kawasan obyek wisata snorkeling menunjukkan bahwa telah terjadi suatu perubahan sosial terkait dengan pola pikir tentang pekerjaan pada masyarakat Pulau Gili Ketapang. Masyarakat Pulau Gili Ketapang telah mengalami kemajuan pola pikir yang lebih maju, terbuka, dan inovatif terkait dengan pekerjaan dengan cara memanfaatkan segala potensi yang dimiliki Pulau Gili Ketapang untuk kesejahteraaan masyarakat. Keberadaan obyek wisata snorkeling menimbulkan pergeseran mata pencaharian pada sebagian masyarakat Pulau Gili Ketapang. Dari hasil penelitian, diketahui bahwa mayoritas masyarakat Pulau Gili Ketapang sebelumnya bekerja di laut sebagai nelayan, usaha transportasi perahu, toko kelontong, pekerja serabutan, dan ibu rumah tangga biasa. Namun, setelah adanya obyek wisata snorkeling di Pulau Gili Ketapang sebagian masyarakat mengalami perubahan mata pencaharian dan lebih memilih bekerja di daratan pada sektor pariwisata diantaranya menjadi pelaku usaha jasa snorkeling, kuliner, dan souvenir, sedangkan sisanya tetap menjalankan usaha jasa transportasi perahu.

Alasan utama masyarakat memutuskan untuk berpindah bekerja di daratan yaitu karena pariwisata dianggap lebih menjanjikan dan lebih aman karena tidak bergantung dengan musim dan tidak harus melawan ombak di lautan. Disamping itu masyarakat juga harus berpartisipasi dan turut serta berperan secara aktif agar kawasan obyek wisata snorkeling Pulau Gili Ketapang dapat berkembang dengan baik dan memberikan dampak positif bagi lingkungan serta manfaat bagi masyarakat Pulau Gili Ketapang secara keseluruhan. Keberadaan obyek wisata snorkeling di Pulau Gili Ketapang memberikan dampak terhadap perkembangan sosial masyarakat. Adanya usaha masyarakat untuk berubah mendorong terjadinya proses sosial sehingga timbul suatu interaksi sosial yang menyebabkan perubahan sosial pada masyarakat lokal Pulau Gili Ketapang khususnya masyarakat yang bergerak di sektor pariwisata setelah berinteraksi dengan para wisatawan yaitu masyarakat menjadi lebih melek akan kemajuan teknologi, meningkatnya ilmu pengetahuan, dan semakin bertambahnya pengalaman.

Keberadaan obyek wisata snorkeling di Pulau Gili Ketapang ini juga menyebabkan perubahan pada kondisi ekonomi masyarakat menjadi lebih baik lagi. Dari hasil penelitian, adanya obyek wisata snorkeling ini telah memunculkan banyak jenis lapangan pekerjaan baru yang telah dimanfaatkan dengan baik oleh masyarakat lokal Pulau Gili Ketapang untuk memperbaiki kondisi perekonomian maupun untuk meningkatkan pendapatan. Sebagian masyarakat lokal Pulau Gili Ketapang telah mendirikan berbagai jenis usaha yang berkaitan dengan pariwisata diantaranya seperti jasa transportasi perahu, jasa snorkeling, kuliner, dan penjualan souvenir untuk memenuhi kebutuhan para wisatawan. Dengan demikian masyarakat Pulau Gili Ketapang sebagai tenaga kerja lokal dapat terserap dengan baik sehingga pendapatan dan kesejahteraan masyarakat menjadi meningkat.

\section{Pembahasan}

Dijadikannya Pulau Gili Ketapang sebagai obyek wisata snorkeling membuat kondisi lingkungan Pulau Gili Ketapang semakin membaik dan bernilai ekonomis. Sebagian masyarakat Pulau Gili Ketapang telah memanfaatkan keberadaan obyek wisata snorkeling tersebut dengan mendirikan beberapa jenis usaha terkait dengan pariwisata diantaranya meliputi usaha transportasi perahu, jasa snorkeling, kuliner, dan penjualan souvenir. Dengan adanya partisipasi masyarakat lokal Pulau Gili Ketapang di sektor usaha, menimbulkan kepuasaan pada diri para wisatawan obyek wisata snorkeling Pulau Gili Ketapang yang merasa bahwa kebutuhannya selama melakukan aktivitas wisata telah dapat terpenuhi dengan baik. Hal tersebut sesuai dengan pendapat dari (Gunn and Var dalam Maruwu, 2017) yang mengemukakan bahwa suatu kawasan wisata yang baik dan berhasil secara optimal didasarkan pada beberapa aspek, yaitu mempertahankan kelestarian lingkungannya, meningkatkan kesejahteraan masyarakat di kawasan tersebut, menjamin kepuasaan pengunjung, meningkatkan keterpaduan dan kesatuan pembangunan masyarakat disekitar kawasan dan zona pengembangan. Disamping itu, (Suwantoro, 2004:15) mengemukakan bahwa dalam kepariwisataan terdapat beberapa komponen yang diperlukan sebagai berikut:

a) Sarana pokok pariwisata yang terdiri dari biro perjalanan dan agen, transportasi, restoran, obyek wisata, dan atraksi wisata

b) Sarana pelengkap pariwisata yang terdiri dari fasilitas rekreasi dan olahraga, serta prasarana umum

c) Sarana penunjang pariwisata seperti toko souvenir 
Berkaitan dengan komponen pariwisata, Pulau Gili Ketapang yang berstatus sebagai daerah wisata bahari tentunya telah memenuhi beberapa komponen pariwisata seperti yang telah dikemukakan oleh Suwantoro diatas meliputi sarana pokok, pelengkap, maupun penunjang. Sarana pokok yang ada di kawasan obyek wisata snorkeling Pulau Gili Ketapang meliputi aktivitas snorkeling sebagai sebuah atraksi wisata yang bisa dilakukan para wisatawan untuk menikmati keindahan dan kekayaan alam bawah laut Pulau Gili Ketapang serta jasa transportasi perahu yang akan mengantarkan para wisatawan menuju dan melakukan aktivitas snorkeling di Pulau Gili Ketapang, disamping itu juga terdapat warung-warung makan yang dapat dimanfaatkan para wisatawan selama menghabiskan waktu dengan mencoba dan menikmati kuliner khas Pulau Gili Ketapang. Berkaitan dengan sarana pelengkap obyek wisata snorkeling Pulau Gili Ketapang memiliki banyak spot foto menarik dan sebuah lapangan voli pantai sebagai fasilitas rekreasi dan olahraga serta sejumlah prasarana umum seperti toilet dan gazebo yang dapat dimanfaatkan para wisatawan untuk bersantai sambil menikmati hamparan pasir putih, suara deburan ombak, dan desiran angin laut di sekitar kawasan obyek wisata snorkeling Pulau Gili Ketapang. Sedangkan untuk sarana penunjang, terdapat beberapa toko yang menjual souvenir khas Pulau Gili Ketapang yang dapat diburu oleh wisatawan sebagai oleh-oleh atau penunjang selama melakukan aktivitas wisata. Dari semua komponen pariwisata yang ada di Pulau Gili Ketapang tersebut, menandakan bahwa selama ini Pulau Gili Ketapang telah memiliki kelayakan menjadi sebuah daerah wisata khususnya snorkeling.

Perubahan pola pikir tentang pekerjaan menjadi lebih maju, terbuka, dan inovatif yang terjadi pada masyarakat Pulau Gili Ketapang merupakan suatu hal yang positif bagi perkembangan sosial masyarakat Pulau Gili Ketapang. Seperti pendapat dari (Sari dkk, 2015:5-6) yang mengemukakan bahwa pola pikir merupakan sekumpulan kepercayaan atau cara berpikir yang mempengaruhi perilaku dan sikap seseorang, yang akhirnya akan menentukan level keberhasilan hidupnya. Oleh karena itu, demi mencapai kondisi sosial yang lebih baik lagi, pola pikir dapat berubah seiring dengan perkembangan zaman, termasuk dengan pola pikir masyarakat Pulau Gili Ketapang tentang pekerjaan yang saat ini telah mengalami perubahan setelah adanya obyek wisata snorkeling. Hal tersebut sesuai dengan pendapat dari (Ogburn dalam Djazifah, 2012:5) yang menjelaskan bahwa perubahan sosial menekankan kepada kondisi teknologis yang menyebabkan terjadinya perubahan pada aspekaspek kehidupan sosial, seperti kemajuan ilmu pengetahuan dan teknologi yang sangat berpengaruh terhadap pola pikir masyarakat. Perubahan pola pikir tentang pekerjaan yang dialami masyarakat Pulau Gili Ketapang pada akhirnya menimbulkan pergeseran mata pencaharian atau perubahan jenis pekerjaan oleh sebagian masyarakat di kawasan obyek wisata snorkeling Pulau Gili Ketapang dengan memilih bekerja di daratan pada sektor pariwisata diantaranya menjadi pelaku usaha jasa snorkeling, kuliner, dan souvenir, sedangkan sisanya tetap menjalankan usaha jasa transportasi perahu, tentunya perubahan tersebut juga dinilai positif bagi perkembangan masyarakat Pulau Gili Ketapang karena masyarakat memiliki alternatif pilihan terkait dengan pekerjaan yang akan digeluti dan minim resiko.

Keberadaan obyek wisata snorkeling di Pulau Gili Ketapang memberikan dampak terhadap perkembangan sosial masyarakat. Setiap masyarakat akan selalu mengalami perubahan, walaupun perubahan yang terjadi tersebut hanya dalam taraf yang kecil atau bahkan perubahan yang sangat besar sehingga akan berpengaruh terhadap aktivitas dan perkembangan masyarakat di masa mendatang. Hal tersebut sesuai dengan pendapat dari (Gillin L. dan Gillin P. dalam Djazifah, 2012:5) yang mengartikan perubahan sosial sebagai suatu variasi dari cara hidup yang diterima, akibat adanya perubahan kondisi geografis, kebudayaan material, komposisi penduduk, ideologi, maupun karena adanya difusi dan penemuan baru dalam masyarakat. Interaksi sosial yang terjadi antara masyarakat Pulau Gili Ketapang dengan para wisatawan yang berkunjung ke obyek wisata snorkeling, tentunya juga merupakan sesuatu yang bernilai positif bagi perkembangan sosial masyarakat Pulau Gili Ketapang. Seperti pendapat dari (Walgito, 2003:65) yang mengartikan interaksi sosial sebagai hubungan antara individu satu dengan individu, individu dengan kelompok, dan kelompok dengan kelompok, atau sebaliknya sehingga terdapat hubungan yang saling timbal balik. Oleh karena itu, masyarakat Pulau Gili Ketapang sebagai makhluk sosial yang juga merupakan pemain kunci dalam pengelolaan dan pengembangan obyek wisata snorkeling selalu melakukan interaksi dengan para wisatawan sehingga menciptakan suatu hubungan timbal balik diantara keduanya. Hubungan timbal balik tersebut memunculkan berbagai bentuk interaksi. Seperti pendapat dari (Sarwono dan Meinarno, 2009) yang mengemukakan bahwa bentuk-bentuk interaksi sosial meliputi kerja sama, persaingan, konflik, dan akomodasi. Bentuk interaksi sosial yang terjadi antara masyarakat Pulau Gili Ketapang dengan para wisatawan obyek wisata snorkeling adalah kerja sama yang merupakan suatu kegiatan yang dilakukan bersama-sama untuk mencapai suatu tujuan dan ada unsur saling membantu satu sama lain. Interaksi sosial yang dilakukan oleh masyarakat dan para wisatawan di kawasan obyek wisata snorkeling Pulau Gili Ketapang pada akhirnya menimbulkan perubahan pada masyarakat Pulau Gili Ketapang menjadi lebih melek akan kemajuan teknologi, meningkatnya ilmu pengetahuan, dan semakin bertambahnya pengalaman. 
Keberadaan obyek wisata snorkeling di Pulau Gili Ketapang juga memberikan dampak terhadap kondisi ekonomi masyarakat menjadi lebih baik lagi dan tentunya bernilai positif bagi tingkat kesejahteraan masyarakat Pulau Gili Ketapang. Hal tersebut sesuai dengan pendapat dari (Stynes dalam Disbudpar Banten, 2013:20) yang mengelompokkan dampak ekonomi menjadi 3 bagian sebagai berikut:

a) Direct effect meliputi penjualan, kesempatan kerja, pendapatan pajak, dan tingkat pendapatan

b) Indirect effect, meliputi perubahan tingkat harga, perubahan mutu dan jumlah barang dan jasa, perubahan dalam penyediaan properti dan variasi pajak, serta perubahan sosial dan lingkungan

c) Induced effects, yaitu pengeluaran rumah tangga dan peningkatan pendapatan.

Berkaitan dengan perubahan kondisi ekonomi masyarakat, Pulau Gili Ketapang yang berstatus sebagai daerah wisata bahari tentunya telah mengalami dampak ekonomi seperti yang telah dikemukakan oleh Stynes diatas. Direct effect yang dialami oleh masyarakat Pulau Gili Ketapang adalah dengan munculnya kesempatan kerja yang telah dimanfaatkan oleh masyarakat lokal seperti membuka usaha yang berkaitan dengan pariwisata ataupun menjadi pekerja di kawasan obyek wisata snorkeling. Indirect effect yang dapat dirasakan adalah perubahan sosial masyarakat yang ditunjukan dengan perubahan pola pikir tentang pekerjaan dan munculnya berbagai bentuk interaksi sosial antara masyarakat dengan para wisatawan obyek wisata snorkeling, serta kondisi lingkungan Pulau Gili Ketapang yang semakin membaik dan bernilai ekonomis setelah sebelumnya sempat mengalami kerusakan akibat penambangan yang dilakukan oleh masyarakat. Sedangkan Induced effect yang dapat dirasakan oleh masyarakat Pulau Gili Ketapang dengan adanya obyek wisata snorkeling ini adalah terjadinya peningkatan pendapatan yang signifikan. Kondisi ekonomi yang mengalami peningkatan tersebut tidak lepas dari pembangunan ekonomi yang dilakukan oleh masyarakat Pulau Gili Ketapang itu sendiri. Seperti pendapat dari (Walt Withman Rostow dalam Deliarnov, 2014:188-189) yang mengemukakan bahwa dalam pembangunan ekonomi terdapat beberapa tahapan diantaranya yaitu tahap perekonomian tradisional statis, tahap transisi, tahap lepas landas, tahap menuju kedewasaan, dan tahap konsumsi massa. Dari kelima tahapan tersebut, saat ini masyarakat Pulau Gili Ketapang tengah berada pada tahap transisi, yaitu tahap dimana ilmu pengetahuan dan teknologi mulai berkembang, produktivitas semakin meningkat, mulai beralihnya tenaga kerja ke sektor industri, muncul semangat baru dari masyarakat untuk menjadi lebih dinamis atau dengan kata lain telah terjadi perubahan paradigma berpikir. Seperti yang telah diketahui bahwa sebelumnya masyarakat Pulau Gili Ketapang merupakan masyarakat nelayan yang saat ini sebagian masyarakatnya telah bergeser menjadi masyarakat yang bergerak di sektor industri pariwisata.

\section{PENUTUP}

\section{Kesimpulan}

Berdasarkan hasil penelitian, maka dapat diambil kesimpulan bahwa dari segi sosial, masyarakat Pulau Gili Ketapang telah mengalami kemajuan pola pikir, terbuka, dan inovatif terkait dengan pekerjaan dengan cara memanfaatkan segala potensi yang dimiliki Pulau Gili Ketapang untuk kesejahteraaan masyarakat. Interaksi sosial yang terjadi antara masyarakat dengan para wisatawan menjadikan masyarakat melek akan kemajuan teknologi, ilmu pengetahuan dan pengalaman yang semakin meningkat. Dari segi ekonomi, keberadaan obyek wisata snorkeling memunculkan jenis lapangan pekerjaan baru yang mampu menyerap tenaga kerja dari usahausaha yang didirikan oleh masyarakat lokal diantaranya yaitu jasa transportasi perahu, jasa snorkeling, kuliner, dan penjualan souvenir. Hal tersebut membuat pengangguran khususnya para generasi muda Pulau Gili Ketapang dapat berkurang dan pendapatan masyarakat mengalami peningkatan yang signifikan.

\section{DAFTAR PUSTAKA}

Badan Pusat Statistik. 2017. Kecamatan Sumberasih Dalam Angka. Kabupaten Probolinggo: Badan Pusat Statistik Kabupaten Probolinggo.

Deliarnov. 2014. Perkembangan Pemikiran Ekonomi. Jakarta: Rajawali Pers.

Dimas, M. dan Prasetya, W. 2016. Modul Pelatihan Skindiving/Snorkeling. Academia.

Dinas Pariwisata dan Kebudayaan. 2013. Analisis Dampak Sosial Ekonomi Kawasan Ekonomi Khusus Pariwisata Tanjung Lesung. Provinsi Banten.

Djazifah, N. 2012. Proses Perubahan Sosial Di Masyarakat. Lembaga Penelitian Dan Pengabdian Kepada Masyarakat. Universitas Negeri Yogyakarta.

Kementrian Pariwisata RI. 2009. Undang-undang RI Nomor 10 Tahun 2009 Tentang Kepariwisataan. Jakarta: 
Kementrian Pariwisata RI.

Sari, R. Dkk. 2015. Faktor-Faktor Yang Mempengaruhi Pola Pikir Masyarakat Terhadap Pentingnya Pendidikan Di Desa Cugur. Jurnal Kultur Demokrasi.

Sarwono dan Meinarno. 2009. Psikologi Sosial. Jakarta: Salemba Humanika.

Suwantoro, G. 2004. Dasar-dasar Pariwisata. Yogyakarta: Andi.

Waruwu, M. 2017. Pengembangan Destinasi Pariwisata Di Kepulaun Nias. http://kabarnias.com/kanal/pariwisata/pengembangan-destinasi-pariwisata-di-kepulauan-nias-8592 [14 Desember 2017]. 